JURNAL REKA YASA PROSES
Volume 11 No.2,2017, hal. 94-100
Journal homepage: http://journal.ugm.ac.id/jrekpros

\title{
Analisis Pengaruh Bahan Dasar terhadap Indeks Viskositas Pelumas Berbagai Kekentalan
}

\author{
Rini Siskayanti dan Muhammad Engkos Kosim \\ Program Studi Teknik Kimia, Fakultas Teknik, Universitas Muhammadyah Jakarta \\ Gedung B Lt 1-3 Jl Cempaka Putih Tengah RT 11 RW 5, Jakarta Pusat, 10510 \\ *Alamat korespondensi: rininovar@gmail.com
}

(Submisi: 11 Desember 2017; Revisi: 27 Desember 2017; Penerimaan: 27 Desember 2017)

\begin{abstract}
$A B S T R A C T$
Lubricants are chemicals, which are generally liquid, provided between two moving objects to reduce frictional forces. The lubricant is made of a 70-90\% base oil mixture and added with an additive to enhance its properties. Basic lubricants can be grouped into 3 i.e. mineral lubricants, vegetable lubricants and synthetic lubricants. One of the functions of lubricants is as an engine coolant from heat arising from friction and sealing. Lubricant resistance to temperature changes is strongly influenced by the type of lubricant base material. The purpose of this research is to know the influence of basic material of lubricant to temperature change as measured by Viscosity Index value. Research done by making machine lubricant with various viscosity with addition of same additives, with the difference in the type of lubricants but still refers to the standard lubricant characteristic tested. Among rive samples tested, which were DEO API CI-4 SAE 15W-40, API PCMO SN SAE 10W40, API MCO SL SAE 10W-30, HO ISO VG 32, and TO API TO-4 SAE 10W, it was observed that lubricant using synthetic materials foundations have higher viscosity index values than minerals (13$30 \%$ higher). Higher viscosity index values indicate that the quality of lubricants is also getting better.
\end{abstract}

Keywords: Mineral lubricant, synthetic lubricant, viscosity index

\begin{abstract}
A B S T R A K
Pelumas adalah zat kimia yang umumnya berupa cairan, yang diberikan di antara dua benda yang bergerak dengan tujuan untuk mengurangi gaya gesek. Pelumas dibuat dari 70-90\% campuran minyak pelumas dasar dan ditambah dengan bahan aditif untuk meningkatkan sifat-sifatnya. Minyak pelumas dasar dapat dikelompokkan menjadi 3 yaitu minyak pelumas mineral, minyak pelumas sintetis dan minyak pelumas nabati. Pelumas mineral adalah pelumas yang dibuat dengan bahan baku minyak pelumas dasar mineral (golongan I dan II) dan pelumas sintetis adalah pelumas yang dibuat dari minyak pelumas dasar sintetis (golongan III, IV, V). Semakin tinggi golongan bahan dasar pelumas maka kualitas pelumas akan semakin baik. Ketahanan pelumas terhadap perubahan temperatur sangat dipengaruhi oleh jenis bahan dasar pelumas. Tujuan penelitian ini untuk mengetahui pengaruh bahan dasar pelumas terhadap perubahan temperatur yang diukur dengan nilai indeks viskositas. Penelitian dilakukan dengan cara membuat pelumas mesin pada berbagai kekentalan dan penambahan aditif yang sama. Jenis minyak pelumas dasar yang digunakan berbeda tetapi mengacu pada standar karakteristik pelumas yang diuji. Dari 5 sampel yang diuji yaitu DEO API CI-4 SAE 15W-40, PCMO API SN SAE
\end{abstract}


10W-40, MCO API SL SAE 10W-30, HO ISO VG 32, dan TO API TO-4 SAE 10W menunjukkan bahwa pelumas dengan menggunakan bahan dasar sintetis mempunyai nilai indeks viskositas yang lebih tinggi jika dibandingkan yang mineral (13-30\% lebih tinggi). Hal ini menunjukkan bahwa kualitas pelumas juga semakin baik.

Kata kunci: Pelumas mineral, pelumas sintetis, indeks viskositas

\section{Pendahuluan}

Pelumas adalah zat kimia yang umumnya berupa cairan yang diberikan di antara dua benda bergerak dengan tujuan untuk mengurangi gaya gesek. Sedangkan pelumasan adalah tindakan menempatkan pelumas antara permukaan yang saling bergeser untuk mengurangi keausan dan friksi (Sukirno, 2010). Kebutuhan pelumas di Indonesia saat ini terus meningkat seiring dengan berkembangnya teknologi kendaraan bermotor serta mesin-mesin industri. Salah satu penggunaan pelumas paling utama adalah pelumas mesin yang dipakai pada mesin pembakaran dalam (internal combustion). Minyak pelumas mesin atau yang lebih dikenal sebagai oli mesin banyak ragam dan macamnya. Bergantung pada jenis penggunaan mesin itu sendiri yang membutuhkan oli yang tepat untuk menambah atau mengawetkan usia pakai (life time) mesin. Keadaan optimum pelumasan logam dapat dicapai jika permukaan logam yang bersentuhan dilapisi secara sempurna oleh minyak pelumas, guna mendapatkan minyak pelumas yang sempurna. Karakteristik dan jenis oli yang digunakan harus diperhatikan (Mujiman, 2011).

Pelumas mesin yang banyak beredar di pasaran saat ini secara komersial adalah jenis pelumas dengan bahan dasar minyak mineral dan minyak sintetis. Pelumas berbahan dasar minyak mineral berasal dari minyak mentah yang biasanya terdiri dari senyawa parafin, naftalena, dan aromatik (Nugrahani, 2007). Minyak mineral ini memiliki sifat tidak berwarna, transparan, tidak berbau, dan tersusun dari campuran senyawa organik sederhana. Kelebihan dari minyak pelumas berbahan dasar mineral adalah memiliki sifat fisik dan kimia yang mudah dikontrol, harganya murah dibandingkan minyak pelumas berbahan dasar sintetis, mudah dicampur dengan bahan aditif untuk menambah kualitas pelumas. Minyak pelumas berbahan sintetis merupakan minyak pelumas yang biasanya ditambah dengan senyawa kimia tertentu yang tidak ada dalam minyak mineral. Senyawa kimia yang molekulnya dirancang sesuai dengan molekul minyak mineral, dan biasanya ditambah dengan zat aditif yang tujuannya meningkatkan kualitas pelumas. Kelebihan minyak pelumas sintetis ini yaitu kestabilannya terhadap suhu tinggi dan oksidasi cukup tinggi. Jangka waktu penggunaan cukup lama, memiliki sifat penguapan yang rendah, dan meningkatkan kinerja berbagai mesin cukup tinggi. Semakin banyaknya jenis pelumas saat ini, tentu membuat konsumen dihadapkan pada berbagai pilihan pelumas, karena pada umumnya produsen pelumas mengklaim pelumas mereka yang paling baik. Konsumen sangat membutuhkan produk pelumas yang bermutu tinggi dan tersedia pada saat dibutuhkan. Mutu dari minyak pelumas ini salah satunya ditentukan oleh sifat fisika yaitu indeks viskositas. Untuk melihat bagaimana pengaruh perbedaaan jenis minyak dasar (base oil) terhadap mutu dari suatu produk pelumas dilakukan uji karakteristik di laboratorium menggunakan metode uji ASTM yaitu viskositas pada suhu $40^{\circ} \mathrm{C}$ dan $100^{\circ} \mathrm{C}$ (ASTM D445), indeks viskositas (ASTM D2270). Hasil yang ingin dicapai dari penelitian ini adalah mampu mengetahui mutu pelumas mesin yang dibuat dari berbagai jenis bahan dasar jika dilihat dari indeks viskositasnya. Selain itu juga untuk mengetahui jenis minyak pelumas dasar (base oil) mana yang paling baik dan efektif untuk digunakan dalam proses pembuatan pelumas. 
Beberapa hal terkait pemahaman ataupun informasi terkait minyak adalah sebagai berikut:

1. Pelumas dasar

Pelumas dasar adalah sejenis minyak atau campuran minyak yang dapat digunakan sebagai bahan dasar pelumas. Pada formulasi pelumas, $70-90 \%$ campuran merupakan minyak pelumas dasar dan ditambah dengan bahan aditif untuk meningkatkan sifatsifatnya. Pelumas dasar dapat dikelompokkan menjadi tiga (Askew 2004):

a. Minyak pelumas mineral.

Minyak mineral merupakan salah satu jenis minyak pelumas yang banyak digunakan pada saat ini. Pelumas dasar ini merupakan hidrokarbon yang mengalami serangkaian proses pemurnian dan dapat digolongkan menjadi empat jenis, yaitu parafin, olefin, naftanik, dan aromatik. Kandungan lain di dalam minyak mineral adalah sulfur, nitrogen dan logam. Keunggulan penggunaan minyak mineral sebagai pelumas dasar adalah: (1) harga murah (2) daerah suhu operasi lebar, meliputi seluruh pemakaian dalam industri, mesin-mesin transportasi, alat-alat berat lain, (3) penambahan bahan aditif dapat meningkatkan mutu dan kinerja, (4) tidak merusak bantalan (5) stabil selama penyimpanan. Kebutuhan minyak mineral meningkat, sedangkan persediaan minyak bumi di dunia menipis karena bersifat tidak terbarukan. Minyak bumi bersifat tidak terdegradasi karena mengandung senyawa aromatik dan racun.

b. Minyak pelumas nabati

Minyak nabati merupakan pelumas dasar yang berasal dari minyak nabati, misalnya minyak kedelai, minyak sawit, minyak kelapa, minyak biji bunga matahari dan minyak biji jarak. Jika minyak nabati dibandingkan dengan minyak mineral sebagai minyak pelumas dasar, terdapat beberapa keunggulan, yaitu tingginya kemampuan pelumasan, tingginya indeks viskositas, rendahnya kehilangan minyak karena penguapan, tingginya kemampuan terdegradasi dan rendahnya kandungan racun. Minyak nabati sebagai pelumas dasar mempunyai keterbatasan, yaitu rendahnya stabilitas termal, hidrolitik, dan oksidatif, karena mengandung asam lemak tidak jenuh. Kelemahan ini dapat diatasi dengan memodifikasi minyak tersebut dengan menambahkan bahan aditif.

c. Minyak pelumas sintetis

Minyak pelumas yang dibuat dengan proses kimiawi dengan menggabungkan beberapa bahan aditif. Pada awalnya, pelumas yang digunakan pada kendaraan tempo dulu adalah berasal dari minyak bumi, pada perkembangannya tidak mampu melayani mesin-mesin dengan teknologi tinggi maka dilakukan penambahan bahan aditif. Selanjutnya, hasil penelitian menunjukkan bahwa pelumas konvensional dari minyak bumi yang telah ditambah dengan bahan aditif, tidak mampu mendukung kinerja mesin baru, maka dilakukan penggantian dengan bahan lain yang bukan berasal dari minyak bumi. Bahan ini merupakan bahan kimia yang memiliki kemampuan lebih unggul daripada minyak mineral dalam semua sifat dasar yang diperlukan, maka terbentuklah pelumas sintetis (Nugroho, 2005)

Pelumas sintetis dapat dikelompokkan dalam dua kelas, yaitu ester organik dan hidrokarbon yang diolah secara sintetis, baik yang berasal dari petrokimia maupun oleokimia. Beberapa pelumas dasar sintetis adalah polialfaolefin (PAO), ester sintetis, seperti monoester, diester, esterphtalat, poliolester (POE), dan ester kompleks dan polialkilenglikol (PAG), yaitu polimer petrokimia hasil reaksi antara etilen oksida dan propilen oksida (Nugrahani, 2008).

2. Klasifikasi pelumas berdasarkan kekentalan Berdasarkan viskositas atau kekentalan yang dinyatakan dalam nomor-nomor Society of Automotive Engineer (SAE). Angka SAE yang lebih besar menunjukkan minyak pelumas yang lebih kental. 
a. Oli monograde, yaitu oli yang indeks kekentalannya dinyatakan hanya satu angka. Contoh DEO SAE 30.

b. Oli multigrade, yaitu oli yang indeks kekentalannya dinyatakan dalam lebih dari satu angka. Contoh DEO SAE 15W-40.

3. Karakteristik mutu pelumas

Oli atau minyak pelumas memiliki ciri-ciri fisik antara lain :

a. Viskositas

Viskositas atau kekentalan suatu minyak pelumas adalah pengukuran dari mengalirnya bahan cair dari minyak pelumas, dihitung dalam ukuran standar. Makin besar perlawanannya untuk mengalir, berarti makin tinggi viskositasnya, begitu pula sebaliknya.

b. Indeks viskositas

Tinggi rendahnya indeks ini menunjukkan ketahanan kekentalan minyak pelumas terhadap perubahan suhu. Makin tinggi angka indeks minyak pelumas, makin kecil perubahan viskositas-nya pada penurunan atau kenaikan suhu. Nilai indeks viskositas ini terbagi dalam 3 golongan, yaitu:

- High Viscosity Index (HVI) di atas 80.

- Medium Viscosity Index (MVI) 40-80.

- Low Viscosity Index (LVI) di bawah 40.

\section{Metode Penelitian}

Penelitian ini dilakukan dengan cara membuat pelumas berupa campuran aditif yang sama tapi bahan dasar berbeda. Bahan dasar yang digunakan yaitu DEO API CI-4 SAE 15W-40, PCMO API SN SAE 10W-40, MCO API SL SAE 10W-30, HO ISO VG 32, dan TO API TO4 SAE 10W. Bahan dasar dan aditif dicampurkan dan dipanaskan di penangas (hot plate). Pengadukan dilakukan dengan magnetic stirrer sampai bahan tercampur homogen. Kemudian uji karakteristik pelumas dilakukan dengan menggunakan metode pengujian ASTM pelumas yaitu viskositas pada suhu $40^{\circ} \mathrm{C}$ dan $100^{\circ} \mathrm{C}$ (ASTM D445) serta indeks viskositas (ASTM D2270). Pengujian dilakukan di Laboratorium Pelumas Independent.

\subsection{Cara penelitian}

Cara kerja penelitian ini disajikan pada diagram alir Gambar 1.

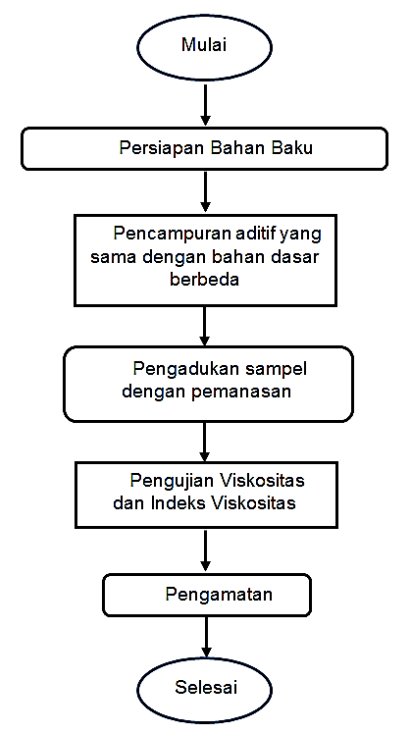

Gambar 1. Diagram alir penelitian

\section{Hasil dan Pembahasan}

Dalam penelitian ini, beberapa macam jenis pelumas dibandingkan kualitasnya pada parameter viskositas kinematik pada suhu $40^{\circ} \mathrm{C}$ dan $100^{\circ} \mathrm{C}$, serta indeks viskositas. Dari masingmasing pelumas tersebut dibuat dalam dua versi yaitu pelumas sintetis dan pelumas mineral untuk membandingkan kualitasnya.

Pelumas mineral adalah pelumas yang dibuat dengan bahan baku minyak pelumas dasar mineral (Grup I dan II) dan pelumas sintetis adalah pelumas yang dibuat dari minyak pelumas dasar sintetis (Grup III, IV, V). Grup I dan II dikatakan pelumas mineral karena minyak pelumas ini berasal dari minyak bumi tanpa ada penambahan senyawa-senyawa buatan. Sementara Grup III, IV, dan V dikatakan minyak pelumas dasar sintetis karena dalam pembuatannya ditambahkan senyawa-senyawa sintetis untuk meningkatkan kualitas minyak pelumas dasar tersebut.

Kualitas pada pelumas sintetis dan mineral berbeda. Ini disebabkan karena perbedaan penggunaan minyak pelumas dasar sebagai bahan baku pelumas tersebut. Dalam penelitian ini pelumas sintetis menggunakan minyak pelumas dasar Grup III, sedangkan pelumas mineral menggunakan minyak pelumas dasar Grup I. 
Semakin tinggi golongan minyak pelumas dasar yang digunakan maka semakin bagus pula kualitas minyak pelumas dasar tersebut tentu saja semakin panjang pula usia pakai pelumas tersebut.

\subsection{Indeks Viskositas}

Indeks viskositas adalah angka yang menunjukkan kualitas dari ketahanan viskositas pelumas terhadap perubahan suhu. Semakin besar angka indeks viskositas maka semakin bagus pula kualitas pelumas tersebut. Dengan kata lain, pelumas yang memiliki indeks viskositas yang tinggi adalah pelumas yang viskositasnya tidak mudah berubah karena adanya perubahan suhu.

Terbukti pada penelitian ini, pada Gambar 2 nilai indeks viskositas pada beberapa macam pelumas sintetis lebih tinggi nilainya dibandingkan dengan pelumas mineralnya. Karena minyak pelumas dasar sintetis lebih stabil viskositasnya terhadap perubahan suhu yang membuat produk pelumas yang dibuat dari minyak pelumas dasar sintetis ini akan meningkat indeks viskositasnya dibandingkan dengan pelumas mineral

Pelumas yang baik adalah pelumas yang memiliki nilai indeks viskositas yang tinggi karena pelumasannya akan berlangsung lebih baik pada rentang perbedaan suhu yang lebih lebar. Dengan demikian fungsi pelumas tersebut sebagai media untuk mengurangi keausan akan berjalan dengan baik.

\subsection{Viskositas Kinematik}

Viskositas mempunyai makna penting karena viskositas merupakan dasar dari pelumasan komponen mesin atau peralatan yang bergerak atau bergesekan. Apabila viskositas tidak tepat maka pelumasan akan gagal, sehingga terjadi keausan bahkan kegagalan mesin. Viskositas sangat dipengaruhi oleh temperatur. Perubahan temperatur mengakibatkan viskositas minyak pelumas juga berubah. Viskositas diukur pada suhu $100^{\circ} \mathrm{C}$ dan suhu $40^{\circ} \mathrm{C}$. Nilai viskositas ini dibatasi minimum dan maksimumnya untuk tiap kelasnya sehingga memudahkan konsumen memilih yang cocok dengan mesin kendaraannya. Nilai viskositas ini terdapat pada tabel SAE J100 Des 1999 dan Standar Nasional Indonesia (SNI). Dari hasil penelitian (Gambar 3 dan 4) dapat dilihat bahwa sampel yang dianalisis terbukti memiliki nilai viskositas pada suhu $100^{\circ} \mathrm{C}$ dan suhu $40^{\circ} \mathrm{C}$ yang masuk dalam spesifikasi yang dipersyaratkan oleh SAE J100 dan SNI.

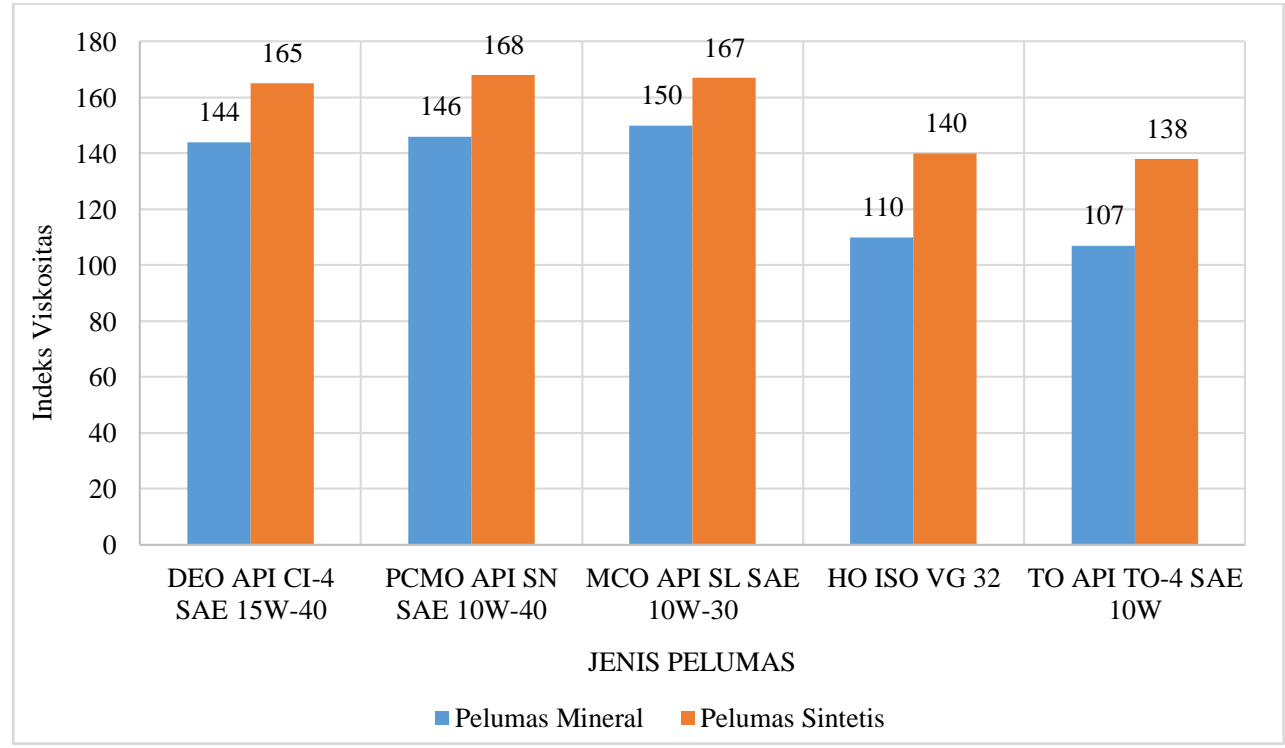

Gambar 2. Diagram hubungan antara indeks viskositas dengan jenis pelumas 


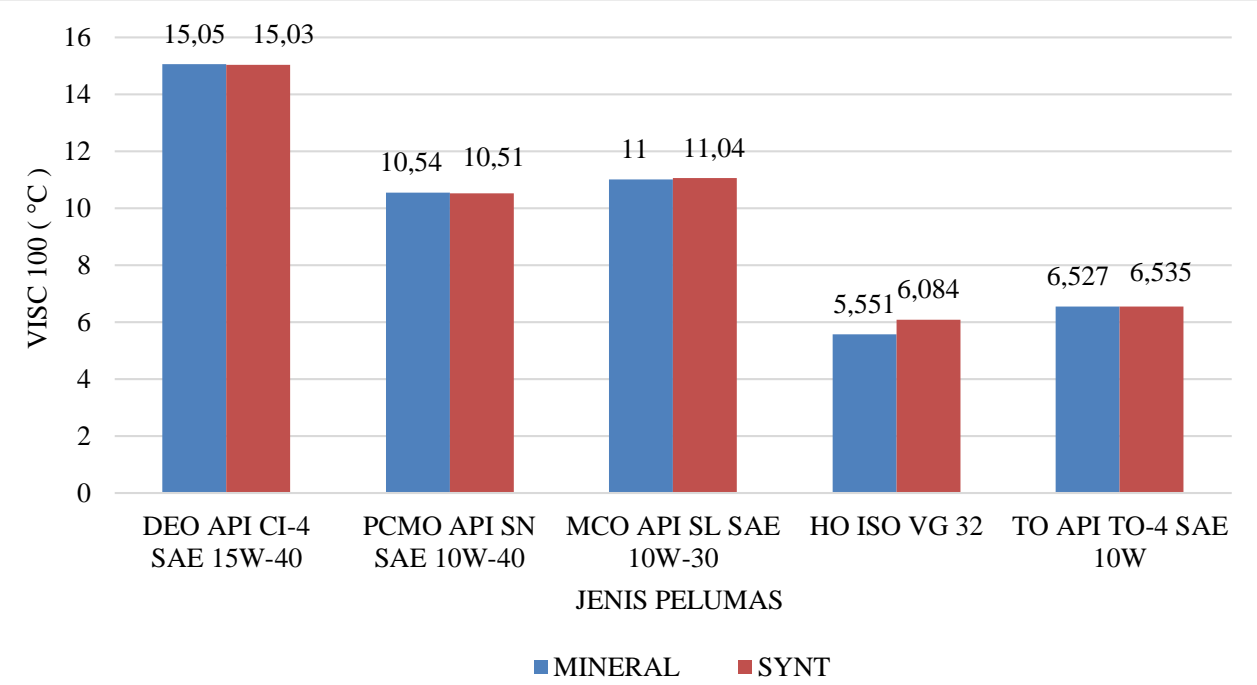

Gambar 3. Diagram hubungan antara viskositas 100 dengan jenis pelumas. $\mathrm{SYNT}=$ syntetic, $\mathrm{VISC}=$ viscosity .

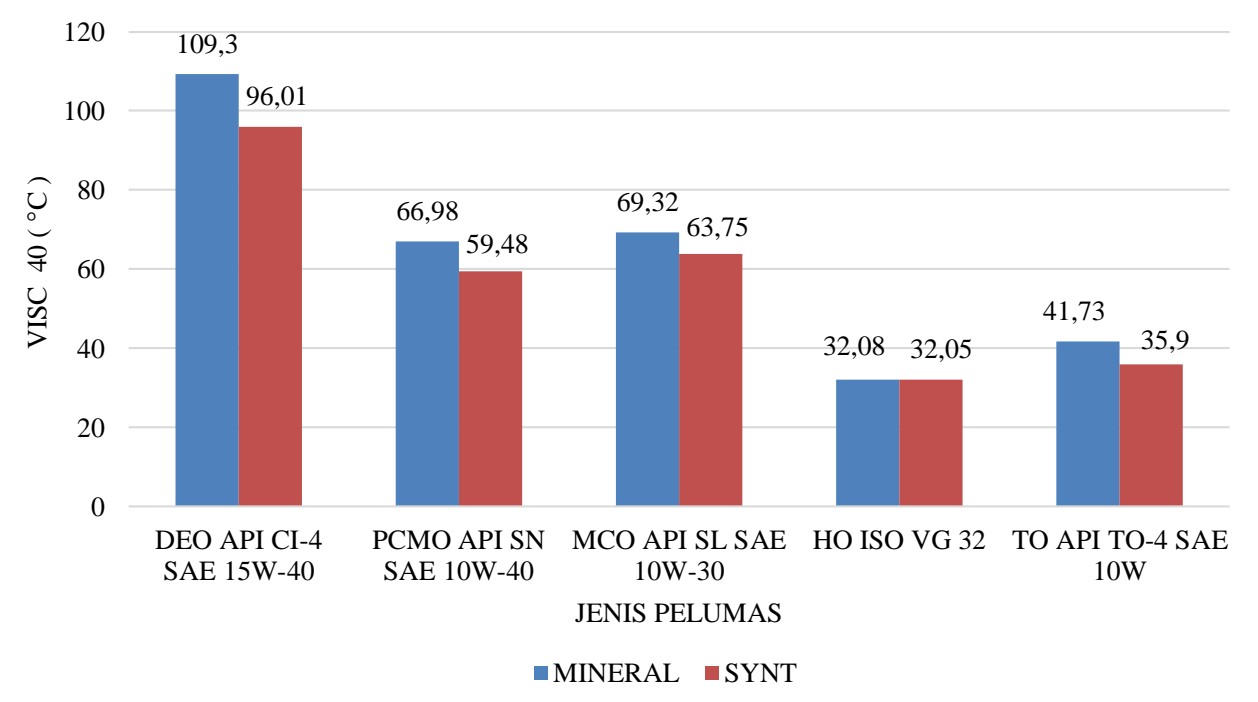

Gambar 4. Diagram hubungan antara viskositas 40 dengan jenis pelumas. SYNT $=$ syntetic, VISC $=$ viscosity.

\section{Kesimpulan}

Berdasarkan hasil penelitian dan pengujian kualitas minyak pelumas sintetis dan mineral pada beberapa jenis pelumas dapat disimpulkan bahwa :

1. Penggunaan minyak pelumas dasar sintetis membuat kualitas pelumas menjadi lebih baik khususnya dari segi viskositas kinematik dan indeks viskositas

2. Semakin bagus atau semakin tinggi golongan bahan baku yang digunakan dalam pembuatan pelumas maka semakin baik kualitasnya serta semakin lama waktu pemakaian pelumas tersebut.

\section{Saran}

Perlu dilakukan pengujian lanjutan terhadap pelumas sintetis menggunakan bahan baku minyak pelumas dasar Grup IV dan V untuk bisa menyimpulkan lebih baik lagi perbedaan dari masing-masing pelumas yang menggunakan bahan baku minyak pelumas dasar Grup IV dan $\mathrm{V}$ dibandingkan dengan minyak pelumas dasar Grup I, II, dan III. 


\section{Ucapan Terima Kasih}

Ucapan terima kasih penulis sampaikan kepada:

1. Direktorat Riset dan Pengabdian Masyarakat, Direktorat Jenderal Penguatan Riset dan Pengembangan Kementrian Riset, Teknologi Pendidikan Tinggi yang telah memberikan dana sesuai dengan Surat Perjanjian Penugasan Pelaksanaan Hibah Penelitian Nomor 0404/K3/KM/2017 Tanggal 24 Mei 2017.

2. Laboratorium Pelumas PT. Wiraswasata Gemilang Indonesia, Desa Ganda Mekar Cikarang Bekasi, yang telah memfasilitas tempat pengujian pada saat penelitatian dilakukan.

\section{Daftar Pustaka}

ASTM D445-11a, 1997, Standard Test Method for Kinematic Viscosity of Transparent and Opaque Liquids (and Calculation of Dynamic Viscosity). ASTM D2270-10, 1997, Standard Practice for Calculating Viscosity Index from Kinematic Viscosity at 40 and $100^{\circ} \mathrm{C}$

Askew, M.F., 2004, Bio-Lubricants-Market Data Sheet, IENICA-Inforrm Project

Mujiman, 2011, Pengukuran nilai viskositas oli MESRAN SAE 10-SAE50 untuk pendingin transformator distribusi dengan penampil LCD, Jurnal Teknologi Technoscientia, 4(1), 1979-8415

Nugrahani, R.A., 2007, Perancangan Proses Pembuatan Pelumas Dasar Sintetis Dari Minyak Jarak Pagar (Jatropha curcas L.) melalui Modifikasi Kimiawi, Disertasi Program Doktor, Institut Pertanian Bogor.

Nugroho A., 2005, Ensiklopedi Otomotif, Penerbit Gramedia Pustaka Utama, Jakarta

Sukirno, 2010, Kuliah Teknologi Pelumas 3, Departemen Teknik Kimia Fakultas Teknik Universitas Indonesia. 